\title{
ANALYSIS OF PROTEIN CONCENTRATE FROM KAHAI (CARYODENDRON ORINOCENSE KARST) SEEDS CULTIVATED IN AMAZONIA OF ECUADOR
}

\author{
GREFFA J ${ }^{1}$, VILCACUNDO E $^{2}$, ALTUNA J $^{2}$, CARRILLO W ${ }^{2 *}$ \\ ${ }^{1}$ Escuela Superior del Chimborazo, Panamericana Sur km 1 1/2, Riobamba, Ecuador. ${ }^{2}$ Department of Research, Faculty of Health and \\ Human Sciences, Bolívar State University, Campus Laguacoto, Guaranda, Ecuador. Email: wi.carrillo@uta.edu.ec
}

Received: 25 May 2017, Revised and Accepted: 24 March 2018

\section{ABSTRACT}

Objective: The aim of this study was to obtain Kahai protein concentrate from Caryodendron orinocense Karst cultivated in the Amazonic region of Ecuador, to characterize its proteins using the sodium dodecyl sulfate-polyacrylamide gel electrophoresis (SDS-PAGE) and native electrophoresis methods, and to determine its content of total polyphenols.

Methods: Kahai seeds (C. orinocense Karst) were utilized to obtain Kahai protein concentrate at pH 3.0, pH 4.0, pH 5.0, and pH 6.0 using the isoelectric precipitation method. The proteins were characterized using the SDS-PAGE and native-PAGE electrophoresis methods. Total polyphenols were determined using the colorimetric assay method.

Results: The best treatment to obtain Kahai protein concentrate was at pH 5.0 with a $21.91 \%$ yield using the cold extraction method. The best treatment was at pH 6.0 with a $11.07 \%$ yield using the heat extraction method. Kahai concentrates presented a complex profile of proteins with molecular weights between 14 and $97 \mathrm{kDa}$. It was possible to obtain at the same time polyphenols at pH 5.0 with a value of $1028.58 \mathrm{mg}$ gallic acid equivalents/100 g protein of sample.

Conclusion: This study suggests that Kahai protein concentrates possess a high content of proteins and polyphenols that can be used to elaborate functional foods.

Keywords: Kahai, Proteins, Kahai protein isolate, Sodium dodecyl sulfate-polyacrylamide gel electrophoresis, Polyphenol.

(C) 2018 The Authors. Published by Innovare Academic Sciences Pvt Ltd. This is an open access article under the CC BY license (http://creativecommons. org/licenses/by/4. 0/) DOI: http://dx.doi.org/10.22159/ajpcr.2018.v11i6.20223

\section{INTRODUCTION}

Proteins, starch, and oil are important components of vegetal foods sources. World population is increasing with a high demand of vegetal foods. New crops are necessary so that these components can be obtained from new food sources. Caryodendron orinocense Karst, named Kahai, is an Amazonic fruit with a high content of proteins (17.78\%), lipids (28.29\%), and carbohydrates (34.60\%) [1]. Lipids from Kahai seeds are used to elaborate different pharmaceutical and cosmetic products, and Kahai proteins are rarely used. The indigenous of Amazonia of Ecuador and Colombia have used Kahai oil in the preparation of ointments and different foods [1,2]. The production of Kahai protein isolate/concentrate using the isoelectric solubilization-precipitation method can be an effective process approach to expand the applications of this low-value flour sub-product in processed vegetal products in countries with this type of crops such as Ecuador and Colombia. The isoelectric solubilizationprecipitation method is a selective, $\mathrm{pH}$-induced solubilization method. In this process, globulin and albumin proteins are first solubilized at either acidic or alkaline $\mathrm{pH}$ values and then separated from fat and insoluble materials (i.e., fibre, carbohydrates). Solubilized proteins are finally precipitated at their isoelectric point, (pI), and isoelectric solubilizationprecipitation processing recovers functional and nutritional proteins at high yields [3-5]. Proteins play a major role in the functional and sensory characteristics of several food products [6], and Kahai protein could be one of these products. The objective of this study was to obtain Kahai protein concentrates of Kahai seeds and their characterization using the electrophoresis method. The polyphenols content was also evaluated.

\section{METHODS}

Kahai protein flour and proximate analysis

Kahai was obtained in the Coca region in Ecuador. The Kahai oil sample was obtained from Kahai seeds using the cold and heat pressing methods. Kahai flour was defatted through extraction with hexane $(1: 10 \mathrm{w} / \mathrm{v})$ at room temperature for $24 \mathrm{~h}$, under continuous stirring during the first $5 \mathrm{~h}$. After drying at room temperature, the flour was stored at $4^{\circ} \mathrm{C}$ until used. Analytical methods such as moisture, fat, total fiber, and soluble solids content were determined, according to the methods of the Association of Official Analytical Chemists (AOAC) [7], numbers $9250.10,930.09,985.29$, and 923.03, respectively. The protein content of the samples was determined using the micro-Kjeldahl method AOAC number 920.152, \% (N×6.25). Carbohydrate percentage was calculated with the formula: \% Carbohydrates $=100-(\%$ moisture $+\%$ proteins $+\%$ fat $+\%$ soluble solids $+\%$ total fiber $)$. Contents were expressed on a dry weight basis.

\section{Protein concentrate obtained from Kahai flour}

Kahai protein concentrate was prepared according to Acosta et al. and Añón [8] with modifications. The defatted flour was suspended in water in a $1: 10 \mathrm{w} / \mathrm{v}$, and the suspension was adjusted to $\mathrm{pH} 8.0$ by adding $2 \mathrm{M} \mathrm{NaOH}$. The suspension was stirred for $1 \mathrm{~h}$ and then centrifuged at

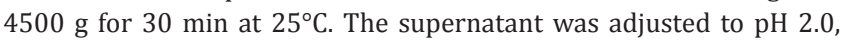
$\mathrm{pH} 3.0, \mathrm{pH} 4.0, \mathrm{pH} 5.0$, and $\mathrm{pH} 6.0$ with $2 \mathrm{~N} \mathrm{HCl}$ and centrifuged for $20 \mathrm{~min}$ at $4500 \mathrm{~g}$. The pellet was suspended in a small volume of water, neutralized with $0.1 \mathrm{M} \mathrm{NaOH}$, lyophilized, and then frozen at $-20^{\circ} \mathrm{C}$. The content of protein isolate was determined using the Dumas method [9].

Sodium dodecyl sulfate-polyacrylamide gel electrophoresis (SDSPAGE)

SDS-PAGE of Kahai protein concentrate was carried out according to the method proposed by Laemmli [10], in the SDS-PAGE system, using $12 \%$ polyacrylamide gel/100 mL of resolving gel; $4 \mathrm{~g}$ acrylamide/100 mL of stacking gel was used in a Mini-PROTEAN Tetra Cell electrophoresis system (Bio-Rad, Hercules, CA, USA). Polypeptide bands were stained in Coomassie Brilliant Blue G-250 for 12 h. Relative molecular masses 
of proteins present in kahai protein concentrate were determined by a comparison to molecular weight markers 6.5-200 kDa kaleidoscope prestained standards (Bio-Rad) which have mix of proteins: myosin (198 kDa), b-galactosidase (125 kDa), bovine serum albumin (BSA) (88 kDa), carbonic anhydrase (37 kDa), soybean trypsin inhibitor (31 kDa), LYS (17 kDa), and aprotinin (6.5 kDa). NATIVE-PAGE analysis of the Kahai protein was carried out by loading samples with $2.5 \mathrm{mg}$ per well and run at $220 \mathrm{~V}$ constant voltage per gel [11]. The stacking gel, separatory gel, and the running buffer were prepared in the same way as in the SDS-PAGE method, except that no SDS was used. Molecular weight calibration kit for SDS electrophoresis (GE Healthcare, Uppsala, Sweden) containing phosphorylase B (97 kDa), BSA (66 kDa), OVA (45 kDa), carbonic anhydrase (37 kDa), trypsin inhibitor (20.1 kDa), and LA (14.4 kDa), was used. Polypeptide bands were stained in Coomassie Brilliant Blue G-250 for $12 \mathrm{~h}$

Analysis of Kahai protein concentrate using reversed-phase ultra-high-performance liquid chromatography (RP-UHPLC) Kahai protein concentrates at $\mathrm{pH}$ 2.0, $\mathrm{pH} 3.0, \mathrm{pH} 4.0, \mathrm{pH} 5.0$, and $\mathrm{pH} 6.0$ were analyzed using RP-UHPLC on Agilent 1200 infinity series UHPLC System (Agilent Technologies, Waldbronn, Germany). The variable wavelength detector was $214 \mathrm{~nm}$. The column used was EC C18 (Agilent Poroshell $120,4.6 \times 50 \mathrm{~mm} \times 2.7 \mu \mathrm{m}$ of particle size). Samples were eluted at $1.0 \mathrm{~mL} / \mathrm{min}$ with a linear gradient from $0 \%$ to $70 \%$ of Solvent B (acetonitrile and trifluoroacetic acid [TFA], 1000:0.270 v/v) in solvent $\mathrm{A}$ (water and TFA, 1000:0.370 v/v) during $10 \mathrm{~min}$. The injection volume was $100 \mu \mathrm{L}$ for each duplicated sample [12].

\section{Extraction of polyphenols}

After the precipitation of Kahai proteins using water at different pHs, the supernatants were separated and then lyophilized for $48 \mathrm{~h}$. Then, the dry samples were stored at $-20^{\circ} \mathrm{C}$.

\section{Determination of total polyphenols}

Total phenolics in the obtained extracts were estimated by a colorimetric assay based on the procedures described by Singleton and Rossi [13] with some modifications. Briefly, $1 \mathrm{~mL}$ of sample was mixed with $1 \mathrm{~mL}$ of Follin-Ciocalteu's phenol reagent. After $3 \mathrm{~min}, 1 \mathrm{~mL}$ of saturated sodium carbonate solution was added to the mixture and adjusted to $10 \mathrm{~mL}$ with distilled water. The reaction was kept in the dark for $90 \mathrm{~min}$. Then, the absorbance was read at $725 \mathrm{~nm}$ using a spectrophotometer (Thermo Scientific Evolution 200). Gallic acid was used for constructing the standard curve $(0-0.075 \mathrm{mg} / \mathrm{mL})$. The results were expressed as mg of gallic acid equivalents (GAEs)/100 g of dry sample.

\section{Statistical analysis}

Results are presented as means \pm standard deviation from three replicates of each experiment. Differences between mean values were determined by the analysis of variance. The post hoc analysis was performed using the Tukey test. All tests were considered statistically significant at $\mathrm{p}<0.05$. The statistical analysis was performed using the software package Prism 4 for Windows, version 4.3 (GraphPad Software Inc., www.graphpad.com)

\section{RESULTS}

\section{Kahai protein concentrates and its protein content}

Kahai oil was extracted using either cold or hot press methods. Residual flour was used to obtain Kahai protein concentrates. This residual flour was defatted using hexane. The defatted Kahai flour was used to obtain Kahai concentrate protein (KCP) using the isoelectric precipitation method at different $\mathrm{pHs}(\mathrm{pH} 3.0, \mathrm{pH} 4.0, \mathrm{pH} 5.0$, and $\mathrm{pH}$ 6.0) with distilled water as solvent. The highest yield with the heat treatment was obtained at pH 5.0 with $11.07 \pm 0.45 \%$. The highest yield with the heat treatment was obtained at $\mathrm{pH} 6.0$ with $21.91 \pm 1.25 \%$ (Table 1). Yields of cold press at $\mathrm{pH} 3.0, \mathrm{pH} 4.0, \mathrm{pH} \mathrm{5.0,} \mathrm{and} \mathrm{pH} 6.0$ presented statistical differences. The contents of protein in the KCP were analyzed using the Dumas method. The treatments at $\mathrm{pH} 3.0$, $\mathrm{pH} 4.0$, pH 5.0, and pH 6.0 presented a higher content of protein. The best treatment identified was at $\mathrm{pH} 5.0$ with a value of $48.32 \%$. At pH 4.0 and $\mathrm{pH} 6.0$, there were no statistical differences with $\mathrm{p}<0.05$ (Table 1). Furthermore, the content of proteins present in Kahai protein concentrates was analyzed using the bicinchoninic acid (BCA) method. The results obtained were similar to the ones obtained using the Dumas method. The best treatment of the BCA method was at $\mathrm{pH} 5.0$ with a value of $50.65 \%$ of protein (Table 1)

The profile of proteins from Kahai seeds was analyzed using the SDSPAGE and native-PAGE electrophoresis methods.

\section{SDS-PAGE analysis}

In the presence of the reductor agent 2-mercaptoethanol, the gel shows that at $\mathrm{pHs} 3.0, \mathrm{pH} 4.0, \mathrm{pH} 5.0$, and at $\mathrm{pH}$ 6.0, there are higher contents of proteins as all bands were strongly stained with the solution of Blue Coomassie used in this study. It has been observed bands with $97,45,21$, and $14 \mathrm{kDa}$ strongly stained with the content of protein (Fig. 1).

Table 1: \% Yield of Kahai protein concentrates obtained at different pHs and content of protein using BCA and Dumas method

\begin{tabular}{lllll}
\hline Method & pH 3.0 & pH 4.0 & pH 5.0 & pH 6.0 \\
\hline $\begin{array}{l}\text { \% Yield } \\
\text { heat }\end{array}$ & $6.98 \pm 0.51^{\mathrm{a}}$ & $9.33 \pm 0.40^{\mathrm{b}}$ & $11.07 \pm 0.45^{\mathrm{c}}$ & $9.76 \pm 0.63^{\mathrm{b}, \mathrm{c}}$ \\
\% Yield & $8.49 \pm 0.27^{\mathrm{a}}$ & $14.08 \pm 0.13^{\mathrm{b}}$ & $16.60 \pm 0.35^{\mathrm{c}}$ & $21.91 \pm 1.25^{\mathrm{d}}$ \\
cold & & & & \\
BCA & $37.54 \pm 4.52^{\mathrm{b}}$ & $36.33 \pm 1.26^{\mathrm{b}}$ & $50.65 \pm 2.82^{\mathrm{a}}$ & $49.65 \pm 4.00^{\mathrm{a}}$ \\
Dumas & $35.05 \pm 0.21^{\mathrm{a}}$ & $37.41 \pm 0.11^{\mathrm{a}}$ & $48.32 \pm 0.22^{\mathrm{a}}$ & $47.79 \pm 0.01^{\mathrm{a}}$ \\
\hline
\end{tabular}

Different letters show statistical difference between the groups $(\mathrm{p}<0.05)$

ANOVA and Tukey's test. BCA: Bicinchoninic acid, ANOVA: Analysis of variance



Fig. 1: Sodium dodecyl sulfate-polyacrylamide gel electrophoresis electrophoresis analysis of Kahai concentrates protein (KCP). Line 1: Molecular weight, Line 2: $\mathrm{KCP}$ at pH 3.0, Line 3: KCP at pH 4.0, Line 4: KCP at pH 5.0, and Line 5: KCP at pH 6.0

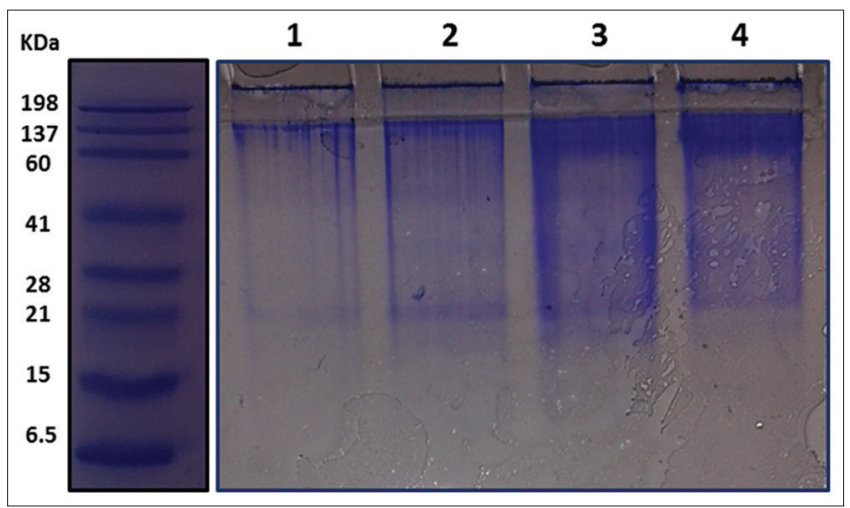

Fig. 2: Native-polyacrylamide gel electrophoresis electrophoresis analysis of Kahai concentrates protein (KCP). Line 1: KCP at pH 3.0, Line 2: KCP at pH 4.0, Line 3: KCP at pH 5.0, and Line 4: KCP at pH 6.0 
Native-PAGE analysis

In the gel of polyacrylamide, it has been observed one band at all $\mathrm{pHs}$ assayed with molecular weight higher than $198 \mathrm{kDa}$. The gel shows bands between 21 and $137 \mathrm{kDa}$. These bands were strongly tinged with the solution Blue Coomassie (Fig. 2).

\section{RP-UHPLC analysis}

All Kahai protein concentrates were analyzed using the RP-UHPLC method for $10 \mathrm{~min}$. The chromatograms show the proteins profile obtained from Kahai seeds. Fig. 3a and b shows four fractions with high capacity of absorbance at $214 \mathrm{~nm}$. These fractions are present in all Kahai concentrates. These results are in accordance with the profile using the electrophoresis method. Fraction 1 (F1) presents low hydrophobicity being very polar [Fig. 3c]. The four fractions have the same time of retention. These proteins are acid proteins as proteins were obtained at low precipitation $\mathrm{pHs}$. At acid $\mathrm{pHs}$, the same proteins were obtained.

\section{Content of polyphenols from Kahai}

The content of polyphenols present in the supernatant after separation of KCP was evaluated (Fig. 4). The content of

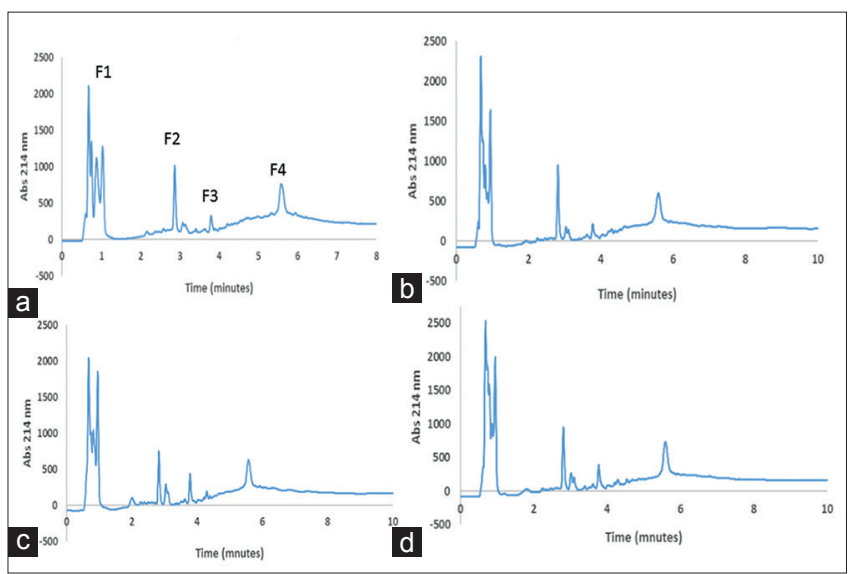

Fig. 3: Reversed-phase ultra-high-performance liquid chromatography of Kahai protein concentrate obtained at different pHs. (a) Kahai protein concentrate at pH 3.0, (b) Kahai protein concentrate at $\mathrm{pH} 4.0$, (c) Kahai protein concentrate at pH 5.0, (d) Kahai protein concentrate at pH 6.0. Column Zorbax EC C18 (Agilent Poroshell 120, 4.6×50 $\mathrm{mm} \times 2.7 \mu \mathrm{m}$ of particle size)

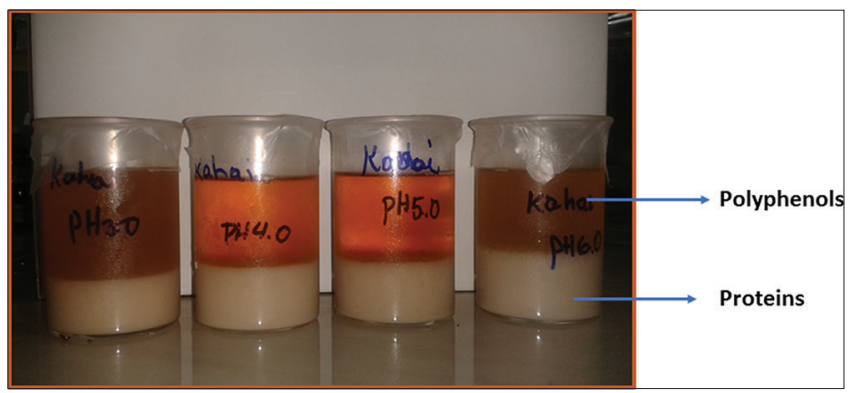

Fig. 4: Obtention of polyphenols with water of Kahai at different pHs polyphenols was determined using a colorimetric assay with the Folin-Ciocalteu's phenol reagent. The highest content of polyphenols was obtained at $\mathrm{pH} 6.0$ with a value of $1028.58 \mathrm{mg} \mathrm{GAE} / 100 \mathrm{~g}$ protein of sample. At $\mathrm{pH}$ 5.0, the content was $962.49 \mathrm{mg} \mathrm{GAE} / 100$ g protein sample. $\mathrm{pH} 3.0$ presents a low value with $644.34 / 100$ g protein of sample (Table 2).

\section{DISCUSSION}

Nowadays, the food industry has a great interest to get new protein sources, and this situation has grown dramatically in the past years [14]. The countries, high cost of proteins from animal sources, health problems such as allergies to animal proteins and many consumers choosing freely to refrain consuming animal proteins. This situation has led to a substantial search for alternative sources of proteins which can replace conventional sources more used $[15,16]$. Alternative sources have been thoroughly studied in recent years with proteins derived from plants (lupin, quinoa, amaranth, and sesame), bacteria, and yeasts being the most promising ones [17]. Among them, oil seeds are a good option as the protein-rich oil cake left after oil extraction is a by-product which can be valorized by the food industry [18]. Kahai seeds are used to extract the oil, and these oils are used for the pharmaceutical and cosmetic industry, but their proteins are less used. The protein content of an oilcake left after oil extraction accounts for $20-50 \%$ on a dry weight basis, similar to soybean which is extensively used in food industry [19]. However, at present, its utilization is limited to the production of animal feed. Kahai protein concentrate at $\mathrm{pH} 5.0$ presents a high content of protein with a value of $50.65 \%$ of protein. Protein concentrates are considered economic if protein content ranges between 35 and $80 \%$ on a dry basis. Protein isolates are defined to have a protein content higher than $85 \%$. For this reason, this vegetal protein is a good option for uses in the food industry.

The Folin-Ciocalteu's reagent assay is the common method used to determine the total phenolic content (TPC) of nuts. TPCs of nuts, expressed as mg of GAE/100 g of sample, were reported in Phenol-Explorer database [20,21] with a range between 47 and 3673. Chestnut contained the highest TPC (1580-3673 mg GAE/100 g), followed by pecan (1284-2016), walnut (1558-1625), pistachio (867-657), hazelnut (291-835), peanut (0.1-420), almond (47-418), Brazil nut (112-310), cashew (137-274), macadamia (46-156), and pine nut $[22,23]$. In the Phenol-Explorer Database, TPC is reported in fruits with values of orange (278.59 mg GAE/100 g), kiwi (179.71 mg GAE/100 g), mango (174.77 mg GAE/100 g), and papaya (57.60 mg GAE $/ 100 \mathrm{~g}$ ). In this study, we report TPC from Kahai with a value range of 644.34-1028.58 mg GAE/100 g in the samples analyzed. These values are high when compared to other foods with polyphenols. In the future, studies could identify the polyphenols present in Kahai seeds. Polyphenol and flavonoids have been reported with different biologicals activities such as antibacterial activity [24]. Polyphenols of Kahai could have biological activities such as antioxidant and antimicrobial activities.

\section{CONCLUSIONS}

It was possible to obtain protein concentrate from Kahai seeds (C. orinocense Karst) and by-product flour with water as solvent obtaining high yields of protein content. It was possible to obtain polyphenols with high values. Kahai seeds are a good source of proteins to be used for animal and human nutrition. Kahai seeds can be an important source of bioactive compounds.

Table 2: Content of polyphenols of Kahai

\begin{tabular}{lllll}
\hline Sample & pH 3.0 & pH 4.0 & pH 5.0 & pH 6.0 \\
\hline \% polyphenols & $644.34 \pm 0.00^{\mathrm{a}}$ & $856.56 \pm 0.00^{\mathrm{b}}$ & $962.49 \pm 0.0003^{\mathrm{c}}$ & $1028.58 \pm 0.0009^{\mathrm{d}}$ \\
\hline Different letters show statistical difference between the groups $(\mathrm{p}<0.05)$ ANOVA and Tukey's test. ANOVA: Analysis of variance &
\end{tabular}




\section{REFERENCES}

1. Alfaro Mde J, Alvarez I, El Khor S, de Padilla FC. Functional properties of a protein product from caryodendron orinocense (Barinas nut). Arch Latinoam Nutr 2004;54:223-8.

2. Pérez de R MN, Alfaro Mde J, Padilla FC. Evaluation of 'nuez de barinas' (caryodendron orinocense) oil for possible use in cosmetic. Int J Cosmet Sci 1999;21:151-8.

3. Abugoch LE, Romero N, Tapia CA, Silva J, Rivera M. Study of some physicochemical and functional properties of quinoa (chenopodium quinoa willd) protein isolates. J Agric Food Chem 2008;56:4745-50.

4. Czubinski J, Dwiecki K, Siger A, Lampart-Szczapa E, NogalaKalucka M. Interactions between Lupinus angustifolius seeds lipoxygenase and native phenolic compounds in the model system. Eur Food Res Technol 2012;235:67-73.

5. Khor E, Wong, N. Comparison study of therapeutic properties of proteins and secondary metabolites from Carica papaya. Int J Pharm Pharm Sci 2016;8:153-8.

6. Tan SH, Mailer RJ, Blanchard CL, Agboola SO. Extraction and characterization of protein fractions from Australian canola meals. Food Res Int 2012b;44:1075-82.

7. AOAC. Official Methods of Analysis. Washington, DC, USA: Association of Official Analytical Chemists; 2012.

8. Acosta C, Carpio C, Vilcacundo R, Carrillo W. Identification of proteins isolate from amaranth (Amaranthus caudatus) by sodium dodecyl sulfate-polyacrylamide gel electrophoresis with water and $\mathrm{NaCl} 0.1 \mathrm{~m}$ solvents. Asian J Pharm Clin Res 2016; 9:331-333.

9. Serrano S, Rincón F, García-Olmo J. Cereal protein analysis via Dumas method: Standardization of a micro-method using the Euro vector elemental analyser. J Cereal Sci 2013;58:31-6.

10. Poveda T, Vilcacundo R, Carpio C, Carrillo W. Analysis of sesame proteins isolate (Sesamum indicum L) with water and salt treatment. Asian J Pharm Clin Res 2016; 9:404-407.

11. Quinteros MF, Vilcacunco R, Carpio C, Carrillo W. Isolation of proteins from sacha inchi (Plukenetia volubilis L.) in presence of water and salt. Asian J Pharm Clin Res 2016; 9:193-196.

12. Lara D, Vilcacundo E, Carrillo C, Silva M, Alvarez M, et al. Obtention of protein concentrate and polyphenols from macadamia (Macadamia integrifolia) with aqueous extraction method. Asian J Pharm Clin Res 2017;10:138-142.
13. Singleton VL, Rossi JA. Colorimetry of total phenolics with phosphomolybdic-phosphotungstic acid reagents. Am J Enol Vitic 1965;16:144-58.

14. Toews R, Wang N. Physicochemical and functional properties of protein concentrates from pulses. Food Res Int 2013;52:445-51.

15. Gerzhova A, Mondor M, Benali M, Aider M. A comparative study between the electro-activation technique and conventional extraction method on the extractability, composition and physicochemical properties of canola protein concentrates and isolates. Food Biosci 2015; 11:56-71

16. Tatar F, Tunç MT, Kahyaoglu T. Turkish tombul hazelnut (Corylus avellana L.) protein concentrates: Functional and rheological properties. J Food Sci Technol 2015;52:1024-31.

17. Berghout JA, Venema P, Boom RM, Van der Goot AJ. Comparing functional properties of concentrated protein isolates with freeze-dried protein isolates from lupin seeds. Food Hydrocoll 2015;51:346-54.

18. Achouri A, Nail V, Boye JI. Sesame protein isolate: Fraction, secondary structure and functional properties. Food Res Int 2012;46:360-9.

19. Tan SH, Mailer RJ, Blanchard CL, Agboola SO. Canola proteins for human consumption: Extraction, profile, and functional properties. J Food Sci 2011;76:R16-28.

20. Rothwell JA, Perez-Jimenez J, Neveu V, Medina-Remón A, M'hiri N, García-Lobato P, et al. Phenol-explorer 3.0: A major update of the phenol-explorer database to incorporate data on the effects of food processing on polyphenol content. Database (Oxford) 2013;2013:bat070.

21. Rothwell JA, Urpi-Sarda M, Boto-Ordoñez M, Knox C, Llorach R, Eisner R, et al. Phenol-explorer 2.0: A major update of the phenol-explorer database integrating data on polyphenol metabolism and pharmacokinetics in humans and experimental animals. Database 2012;2012:bas031.

22. Kornsteiner M, Wagner KH, Elmadfa I. Tocopherols and total phenolics in 10 different nut types. Food Chem 2006;98:381-7.

23. Wu X, Beecher GR, Holden JM, Haytowitz DB, Gebhardt SE, Prior RL. Lipophilic and hydrophilic antioxidant capacities of common foods in the United States. J Agric Food Chem 2004;52:4026-37.

24. Hafse M, Farah A, Benbrahim K. Evaluation of the antibacterial activity and determination of polyphenols and flavonoids contents of Moroccan Coriaria myrtifolia extracts. Int J Pharm Pharm Sci 2015;7:108-11. 